\title{
25 HYDROXYVITAMIN D AND CYTOKINES IN MULTIPLE SCLEROSIS
}

Georgi Sv. Slavov 1,4*, Maria G. Manova ${ }^{1}$, Anastasia G. Trenova ${ }^{1}$, Ivanka I. Kostadinova ${ }^{2}$, Pavel I. Pavlov ${ }^{3,5}$, Nonka G. Mateva ${ }^{6}$, Zahari I. Zahariev ${ }^{1,4}$

${ }^{1}$ Department of Neurology, Faculty of Medicine, ${ }^{2}$ Department of Pharmacology and Clinical Pharmacology, Faculty of Medicine, ${ }^{3}$ Department of Clinical Laboratory, Faculty of Pharmacy, Medical University, Plovdiv ${ }^{4}$ Clinic of Neurology, ${ }^{5}$ Central Clinical laboratory, St. George University Hospital, Plovdiv, ${ }^{6}$ Department of Medical Informatics, Biostatistics and E-learning, Faculty of Public Health, Medical University, Plovdiv, Bulgaria

\section{HYDROXYVITAMIN D И ЦИТОКИНЫ ПРИ РАССЕЯННОМ СКЛЕРОЗЕ}

Георги Св. Славов ${ }^{1,4 *}$, Мария Г. Манова ${ }^{1}$, Анастасия Г. Тренова $^{1}$, Иванка И. Костадинова $^{2}$, Павел И. Павлов ${ }^{3,5}$, Нонка Г. Матева ${ }^{6}$, Захари И. Захариев ${ }^{1,4}$

${ }^{1}$ Кафедра неврологии, Медицинский факультет, ${ }^{2}$ Кафедра фармакологии и клинической фармакологии, Медичинский факультет, ${ }^{3}$ Кафедра клинической лаборатории, Факультет фармации, Медииинский университет, Пловдив, ${ }^{4}$ Отделение неврологии, ${ }^{5}$ Центральная клиническая лаборатория, УМБАЛ „Св. Георги” ЕАД, 'Кафедра медииинской информатики, биостатистики и электронного обучения, Факультет общественного здравоохранения, Медииинский университет, Пловдив, Болгария

\begin{abstract}
INTRODUCTION: Clinical trials of patients with multiple sclerosis (MS) have produced inconsistent results for the profile of cytokine secretion in serum and cerebrospinal fluid in patients with multiple sclerosis during periods of relapse and remission. Epidemiological and clinical observations data reveal an association of the changes in vitamin D serum concentration with the risk of developing MS. Aıм: To evaluate changes in serum concentrations of 25(OH)D, IL17, IFN-gamma, TGF $\beta 1$, IL4, IL10 in relapse and remission and their correlation with the severity of disability. Patients and methods: Fifty-three persons (30 clinically healthy controls and 23 patients with relapsing-remitting multiple sclerosis) living between $41^{\circ}$ and $42^{\circ}$ northern latitude were registered during the astronomical winter period (October 2012- May 2013).-Patients were diagnosed according to Mc Donald 2010 criteria. The degree of neurological deficit was assessed by EDSS. Serum concentrations of $25(\mathrm{OH}) \mathrm{D}$ $(\mathrm{nmol} / \mathrm{l})$ and cytokines $(\mathrm{pg} / \mathrm{ml})$ were tested by ELISA - once for controls and twice for patients (during relapse and remission). REsults: In the studied population average levels of $25(\mathrm{OH}) \mathrm{D}$ were close to insufficiency, most pronounced in patients in relapse, as differences were not statistically significant. A reverse correlation was found between the levels of $25(\mathrm{OH}) \mathrm{D}$ and the deficit in relapse and remission. Concentrations of TGF $\beta 1$ significantly increased in remission compared with exacerbation and controls. Serum level of IL4 was significantly lower in relapse compared with controls. In remission there was a marked tendency of increase compared with exacerbation. During clinical improvement IL17 and IFN-gamma tended to decrease compared to the average levels in relapse. In both periods, the average concentrations of IFN-gamma in patients were significantly lower compared with controls. No statistically significant differences were found comparing cytokine changes with those of 25(OH)D and deficit. Conclusion: Persistent cytokine imbalance in patients compared with controls is a marker for Th1-mediated CNS demyelination. Anti-inflammatory TGF $\beta 1$, IL4 are indicators of immune response intensity. The deficit severity does not depend on changes of the tested cytokines, but correlates with 25(OH)D levels during periods of relapse and remission.
\end{abstract}

Key words: vitamin D, cytokines, multiple sclerosis

Folia Medica 2015;57(3\&4):200-206

Copyright (C) 2015 Medical University, Plovdiv

\section{РЕЗЮМЕ}

ЦЕль: Оценить изменения в сывороточных концентрациях 25(OH)D, IL17, IFN-gamma, TGFß1, IL4, IL10 в периоды приступа и ремиссии и их связь с тяжестью инвалидизации. МАтеРиАЛ и мЕтоды: 53 лица (контрольная группа из 30 клинически здоровых лиц и 23 пациента с приступно-ремитентным ходом рассеянного склероза) с местообитанием в координатах $41^{\circ}-42^{\circ}$ северной широты, зарегистрированы в астрономически зимний период (октябрь 2012 - май 2013г.). Диагноз был поставлен в соответствии с критериями Mc Donald 2010. Степень неврологического дефицита оценена при помощи EDSS. Сывороточные концентрации 25(OH)D $(\mathrm{nmol} / \mathrm{l})$ и цитокинов $(\mathrm{pg} / \mathrm{ml})$ исследованы при помощи ELI-

Article's history: Received: 09 Sep 2015; Received in a revised form: 08 Dec 2015; Accepted: 10 Dec 2015

*Correspondence and reprint request to: G. Slavov, Department of Neurology, Faculty of Medicine, Medical University, Plovdiv and Clinic of Neurology, St. George University Hospital, Plovdiv; E-mail: georgi.slavov.15130@gmail.com; Tel.: +359 885247929 
SA - однократно в контрольной группе и двукратно среди пациентов (во время приступа и ремиссии). Результаты: У обследованного контингента средние уровни 25(OH)D находятся на пороге недостаточности, сильнее всего выраженной среди больных в состоянии приступа, без наличия статистически значимых различий. Установлена обратная корреляционная зависимость между уровнями дефицита $25(\mathrm{OH}) \mathrm{D}$ во время приступа и ремиссии ( $\mathrm{r}$ приступ $=-0.593, \mathrm{p}=0.03 ; \mathrm{r}$ ремиссия $=-0.46, \mathrm{p}=0.024)$. Во время ремиссии значительно возрастают концентрации TGF $\beta 1$ по сравнению с экзацербацией $(\mathrm{p}=0,0001)$ и с контрольной группой $(\mathrm{p}=0.001)$. Сывороточный уровень IL4 является сигнификантно более низким во время приступа по сравнению с контрольной группой ( $=0.049)$. Во время ремиссии наблюдается выраженная тенденция повышения по сравнению с экзацербацией $(\mathrm{p}=0.054)$. В период клинического улучшения наблюдается тенденция понижения уровней IL17, IFN-gamma по сравнению со средними уровнями в период приступа. Во время обоих периодов средние концентрации IFN-gamma у пациентов являются сигнификантно более низкими по сравнению с контрольной группой $(\mathrm{p}=0.036, \mathrm{p}=0.05)$. При сопоставлении изменений уровня цитокинов с изменениями уровня дефицита $25(\mathrm{OH}) \mathrm{D}$ не установлены статистически значимые взаимосвязи. ЗАключениЕ: Персистирующий цитокиновый дисбаланс у пациентов по сравнению с контрольной группой является маркером Th1, вызванной демиелинизацией в ЦНС. Антивоспалительные цитокины TGF $\beta 1$, IL4 являются показателями интенсивности иммунной реакции. Тяжесть дефицита не зависит от изменений исследуемых цитокинов, но коррелирует с уровнями $25(\mathrm{OH}) \mathrm{D}$ во время периодов приступа и ремиссии.

Ключевые слова: витамин Д, иүитокины, рассеянный склероз

Folia Medica 2015;57(3\&4):200-206

(C) 2015 Bсе права защищены. Медицинский университет, Пловдив

\section{INTRODUCTION}

Multiple sclerosis (MS) is an immune disorder with multifactorial etiology, characterized by demyelination, axonal transection and oligodendropathy in the central nervous system (CNS). Data obtained in experimental allergic encephalomyelitis (EAE) support the thesis of CD4+ T cell-mediated destruction of the myelin with imbalance in cytokine secretion from Th1, Th17, Th2 lymphocyte subpopulations. In exacerbation the imbalance in the periphery is characterized by reduction of the regulatory CD4+, $\mathrm{CD} 25+$ Foxp 3 subpopulation related to the production of the anti-inflammatory cytokines TGF $\beta 1$, IL10, inhibited synthesis of IL4 and enhanced secretion of proinflammatory cytokines TNF $\alpha$, IFN-gamma, IL17. ${ }^{1,2}$ Clinical studies establish inconsistent results for cytokine secretion profile in serum and cerebrospinal fluid of patients during periods of relapse and remission when compared with controls. ${ }^{3-5}$ The hypothesis of correlation between the pattern of myelin destruction, clinical manifestations, and potential therapeutic response is a reason to examine the involvement of various factors in the etiology and pathogenesis of MS. Extracorporeal vitamin D-factor prevents the development of EAE if administered before the induction with myelin protein and arrests the progress of the disease during treatment after the first clinical signs. ${ }^{6,7}$ Data from epidemiological and clinical observations suggest a link of the changes in serum concentrations of vitamin D with the risk of developing MS, and with the phases of relapse and remission. ${ }^{8,11}$ An indicator of vitamin $\mathrm{D}$ status in the body is the serum concentration of 25 hydroxyvitamin $\mathrm{D} / 25(\mathrm{OH}) \mathrm{D} /$, which correlates with the biologically active metabolite having properties of the hormone 1,25 dihydroxyvitamin $\mathrm{D} / 1,25(\mathrm{OH}) 2 \mathrm{D} / .^{8}$ Data obtained in vitro support the hypothesis of suppressive effect of $1,25(\mathrm{OH}) 2 \mathrm{D}$ on the synthesis of the pro-inflammatory cytokines IFN-gamma, IL17, IL2, of the induction of antiinflammatory Th2 mediated secretion of IL4, IL5, IL13, and of the regulatory CD4+, CD25+ Foxp3 subpopulation. Treatment of EAE with 1,25(OH)2D stimulates the synthesis of IL4 and TGF $\beta 1$. Conflicting results have been reported on minor changes of Th2-mediated secretion of cytokines in the CNS and peripheral organs of the immune system after treatment with $1,25(\mathrm{OH}) 2 \mathrm{D} .{ }^{10,12}$

Research on the causal link between the dynamics in serum concentrations of immune parameters, vitamin D levels and clinical indicators of disease activity will clarify aspects of the mechanism of the immune process so that the therapeutic control of disturbed immune regulation is optimized.

\section{AIM}

To evaluate changes in serum concentrations of IFN-gamma, IL17, TGF $\beta 1$, IL4, IL10, 25(OH)D in relapse and remission phases and their relationship with the degree of neurological deficit. 


\section{PATIENTS AND METHODS}

\section{DESIGN}

The present study is prospective, case-control. Patients were recruited on an outpatient basis at the MS Diagnosis and Treatment Center at St. George University Hospital, Plovdiv, during the winter from October 2012 to May 2013. The research was approved by the Ethics Committee at MU Plovdiv by Protocol № 3/05.07.2012. The design involves a single test of serum IFN-gamma, IL17, TGF $\beta 1$, IL4, IL10, 25(OH)D of the clinically healthy controls and two tests of the patients - during periods of relapse and remission ( $\geq 2$ months after a consecutive relapse). Patients with relapses were routinely hospitalized at the Clinic of Neurology, St. George University Hospital, Plovdiv. Treatment was conducted with methylprednisolone (Sopharma) 500 $\mathrm{mg}$, i.v. in the morning, the course dose $-2500 \mathrm{mg}$.

\section{PATIENTS}

Data of 53 individuals were analyzed. Of these, 30 were controls (15 women, 15 men) and 23 patients (15 women, 8 men) with inpatient monitoring during relapse and outpatient monitoring during remission.

Inclusion criteria - Caucasians community dwelling at $41^{\circ}-42^{\circ}$ northern latitude, aged $18-50$ years; patients with relapsing-remitting MS, degree of neurological deficit - 1.5-5.0 after EDSS;

Exclusion criteria - primary and secondary progressive course; drug treatment modifying the disease course during the year preceding the date of registration; therapy with vitamin $\mathrm{D}$ and drugs affecting the metabolism of vitamin D (oral contraceptives, hormone replacement therapy, anti-epileptic agents, laxatives, thiazide diuretics), accompanying autoimmune diseases, acute and chronic infections, liver, kidney, and neoplastic diseases, hyperparathyroidism, diabetes, hypercalcaemia.

\section{Controls}

Inclusion criteria - clinically healthy, age- and sex-matched subjects who were not on oral con- traceptives, hormone replacement therapy, laxative preparations, or polyvitamins.

\section{Methods}

Clinical methods: Diagnosis was made according to the McDonald criteria (2010). Neurological deficit degree was assessed with the Expanded Disability Status Scale (EDSS, Kurtzke, 1983). Relapse is defined as the onset of new neurological symptoms or worsening of old ones with duration $>24$ hours, aggravation of EDSS $\geq 0.5$ degree in the absence of fever and after a period of 30-day improvement or stable condition after another relapse in succession.

Laboratory methods: Serum concentrations of cytokines IFN-gamma, IL17, TGF $\beta 1$, IL4, IL10 and 25-OH Vitamin D were determined by enzyme-linked immunosorbent analysis with original ELISA-kits, eBioscience, Austria, and original ELISA-kits, Immundiagnostik AG, Germany. Each sample was tested in duplicate analyses. Tests were serially read by ELISA-reader (Sirio- microplate reader, SEAC- Italy) at $450 \mathrm{~nm}$ (reference - $620 \mathrm{~nm}$ ).

\section{Statistical analysis}

The number of observed objects was estimated at $5 \% \alpha$ error and $\beta$ error - 20\%. Quantitative indicators are presented as mean and standard error $1 \pm \mathrm{SEM} /$. Comparison of results between groups was performed using the independent sample $t$ test and Mann-Whitney test at a significance level of $p<$ 0.05 , depending on the results of the KolmogorovSmirnov test. Correlation analysis was also applied. For statistical data processing statistical software SPSS 17.0 was used.

\section{RESULTS}

The clinical characteristics of the participants is presented in Table 1.

Comparison of mean age in patients and controls found no statistically significant differences $(p>$ $0.05, \mathrm{t}=1.316$ ). All patients were registered by the end of the first month of a consecutive relapse (between 3rd and 25th day), the highest proportion

Table 1. Clinical characteristics of participants

\begin{tabular}{|c|c|c|c|c|c|c|}
\hline \multirow{3}{*}{ Groups } & \multirow{3}{*}{ Number } & \multicolumn{2}{|c|}{ Sex } & \multirow{2}{*}{$\frac{\text { Age }}{(\text { mean } \pm \text { SEM })}$} & \multirow{2}{*}{$\begin{array}{c}\text { Duration of illness } \\
(\text { mean } \pm \text { SEM })\end{array}$} & \multirow{2}{*}{$\begin{array}{c}\begin{array}{c}\text { Age at onset of } \\
\text { first signs }\end{array} \\
\text { (mean } \pm \text { SEM })\end{array}$} \\
\hline & & female & male & & & \\
\hline & & (n) & (n) & years & years & years \\
\hline Patients & 23 & 15 & 8 & $35.09 \pm 2.87$ & $7.65 \pm 1.75$ & $27.30 \pm 1.97$ \\
\hline Controls & 30 & 15 & 15 & $31.17 \pm 1.41$ & - & - \\
\hline
\end{tabular}


of registered patients occurring by the end of week 3 $(47.83 \%, \mathrm{n}=11)$. The average degree of neurological deficit in relapse was $2.48 \pm 0.19$; during remission it was $1.72 \pm 0.19$. The deficit decrease was statistically significant during remission compared with relapse $(p<0.001)$. Tables 2 and 3 present results of the tested pro- and anti-inflammatory cytokines in patients and controls during periods of relapse and remission. The following analyses were used: IFN 'Y. IL17 - parametric analysis; for IL4 - parametric analysis, for TGF B1, IL10 - non-parametric Mann-Whitney test.

In remission the mean levels of IFN-gamma and IL17 tended to decrease compared to the levels in relapse. During both periods the mean concentrations of IFN-gamma were significantly lower than those in controls $(\mathrm{p}=0.036$ in relapse, $\mathrm{p}=0.005$ in remission).

During remission mean concentrations of TGF $\beta 1$ increase statistically significantly in comparison with exacerbation $(\mathrm{p}<0.0001)$ and with controls $(\mathrm{p}<0.001)$. The mean concentration of IL4 is significantly lower in relapse than this in controls $(p=0.049)$, but in remission it tends to increase compared with exacerbation period $(\mathrm{p}=0.054)$. No statistically significant differences were found in the dynamics of IL10 in comparisons between patients and controls, relapse and remission. Analysis of mean serum concentrations of $25(\mathrm{OH}) \mathrm{D}$ between controls, patients in relapse and those in remission, did not find any statistically significant differences, but the established trends have to be mentioned. The mean levels in healthy subjects and patients were within the insufficiency range for Bulgarian population (25-49.99 nmol/l), most pronounced in patients with relapse $(\overline{\mathrm{x}}) \pm \mathrm{SEM}$; healthy $-31.46 \pm 7.3$; in relapse $-26.93 \pm 7.44$; in remission - $28.06 \pm 7.28$ ).

During remission average levels increase compared to those in relapse, but fail to reach statistical significance. Results are presented in Fig. 1.

Values for EDSS and 25(OH)D levels in relapse and remission are presented in Figure 2. Correlation analysis (Spearman) found a negative correlation between the concentration of $25(\mathrm{OH}) \mathrm{D}$ in relapse and remission, and the degree of deficit in both periods $\left(\mathrm{r}_{\text {relapse }}=-0.593, \mathrm{p}=0.03 ; \mathrm{r}_{\text {remission }}=-0.46\right.$, $\mathrm{p}=0.027)$.

\section{DISCUSSION}

This study revealed persistent immune disbalance in patients during the two clinical periods in compari-

Table. 2. Serum concentrations of tested proinflammatory cytokines

\begin{tabular}{lcccccc}
\hline \multicolumn{1}{c}{ Cytokines } & $\begin{array}{c}\text { IL17 } \\
(\mathbf{m e a n} \pm \mathbf{S E M}) \\
\mathbf{p g} / \mathbf{m l}\end{array}$ & $\mathbf{p}_{\mathbf{1}}$ & $\mathbf{p}_{\mathbf{2}}$ & $\begin{array}{c}\text { IFN } \mathbf{~}^{\prime} \\
(\mathbf{m e a n} \pm \mathbf{S E M}) \\
\mathbf{p g} / \mathbf{m l}\end{array}$ & $\mathbf{p}_{\mathbf{1}}$ & $\mathbf{p}_{\mathbf{2}}$ \\
\hline Relapse & $69.82 \pm 10.88$ & 0.728 & & $2.04 \pm 0.48$ & $0.036^{*}$ & \\
Remission & $58.50 \pm 11.10$ & 0.073 & 0,520 & $1.31 \pm 0.25$ & $0.005^{*}$ & 0.192 \\
Control & $63.77 \pm 10.88$ & & & $4.55 \pm 0.95$ & & \\
\hline
\end{tabular}

$\mathrm{p}_{1}$ - comparison with controls;

$\mathrm{p}_{2}$ - comparison between relapse and remission.

Table 3. Serum concentrations of tested anti-inflammatory cytokines

\begin{tabular}{|c|c|c|c|c|c|c|c|c|c|}
\hline Cytokines & $\begin{array}{c}\text { IL4 } \\
(\text { mean } \pm \text { SEM) } \\
\text { pg/ml }\end{array}$ & $p_{1}$ & $\mathbf{p}_{2}$ & $\begin{array}{c}\text { IL10 } \\
(\text { mean } \pm \text { SEM) } \\
\text { pg/ml }\end{array}$ & $\mathbf{p}_{1}$ & $\mathbf{p}_{2}$ & $\begin{array}{c}\text { TGF B1 } \\
(\text { mean } \pm \text { SEM) } \\
\text { pg/ml }\end{array}$ & $p_{1}$ & $\mathbf{p}_{2}$ \\
\hline Relapse & $5.29 \pm 1.00$ & $0.049^{*}$ & & $1.68 \pm 1.28$ & 0.986 & & $0.50 \pm 0.04$ & 0.802 & \\
\hline Remission & $8.54 \pm 1.31$ & 0.368 & 0.054 & $1.36 \pm 0.29$ & 0.169 & 0.332 & $0.77 \pm 0.04$ & $0.001 *$ & $0.0001 *$ \\
\hline Controls & $10.99 \pm 2.34$ & & & $1.67 \pm 1.20$ & & & $0.52 \pm 0.05$ & & \\
\hline
\end{tabular}

$\mathrm{p}_{1}$ - comparison with controls;

$\mathrm{p}_{2}$ - comparison between relapse and remission. 


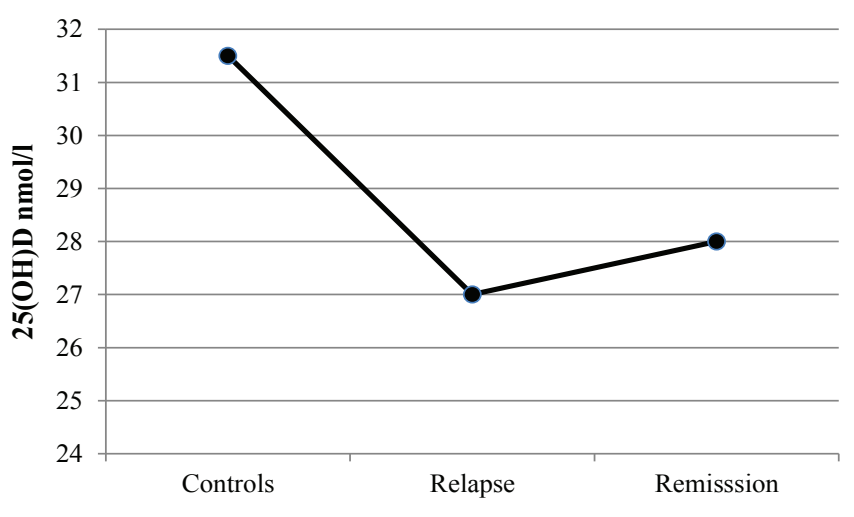

Figure 1. Serum levels of 25(OH)D.

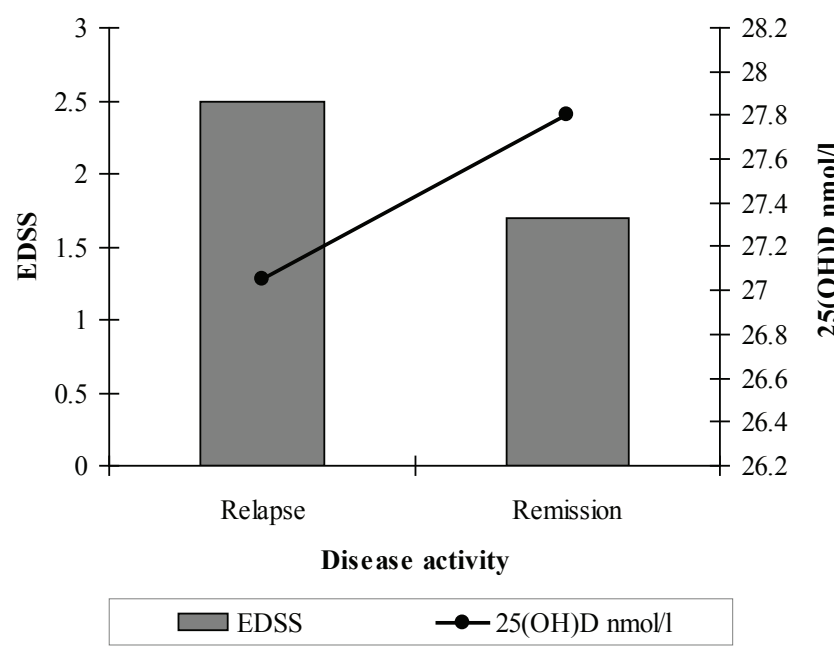

Figure 2. Changes in deficit severity /EDSS/ and serum levels of $25(\mathrm{OH}) \mathrm{D}$.

son with controls. Secretion of cytokine inducers of inflammation - IFN-gamma, IL17 dominates during exacerbation. Various authors find in patients in relapse significantly higher secretion of IFN-gamma from peripheral blood mononuclear cells (PBMC), higher serum levels compared to remission. In brain lesions enhanced production of IFN-gamma, an inducer of oligodendrocyte apoptosis, is detected. ${ }^{13,14}$ We have found statistically significant lower serum levels of IFN-gamma in patients in the two phases compared to controls. We assume that these data are related to the fluctuation of anti-myelin reactivity. $\mathrm{N}$. Hellings et al. find transient increase in IFNgamma, TNF $\alpha$, IL6 before exacerbation. In vitro studies confirm these results. ${ }^{4}$ Research on seasonal fluctuations of cytokines reveals significantly higher IFN-gamma levels in healthy individuals during winter than during summer. ${ }^{15}$ We assume that the obtained results may reflect such an aspect in the dynamics of cytokine secretion. The identified tendency of decrease in serum concentrations of IL17 during remission compared to relapse is consistent with the results reported by V. Brucklacher-Waldert et al. for a significantly higher proportion of IL17 lymphocytes during exacerbation compared to remission. ${ }^{16}$ There has been experimental evidence proving an anti-inflammatory potential of Th17 subpopulation. Results for the increase of mRNA levels in the inflammation areas of the CNS are illustrative for elevated levels of IL17 in the serum and CSF of patients compared with controls. ${ }^{5,17,18}$ No statistically significant difference is found upon comparison of IL17 serum concentrations in patients and controls. Data of Kallaur A. et al. are similar. ${ }^{5}$ We believe that significantly increased levels of TGF $\beta 1$ during remission compared to relapse and controls is the result of enhanced secretion of TGF $\beta 1$ during this period and is an aspect of immune tolerance disorders in patients. Experimental data confirm the regulatory function of TGF $\beta 1$ - retards the development of EAE, reduces the severity of clinical manifestations, suppresses reactivity of proinflammatory cytokines -TNF $\alpha$, IFN-gamma, IL1, IL2, IL6. Clinical studies establish: negative correlation between serum concentrations of TGF $\beta 1$ and magnetic resonance activity; high TGF $\beta 1 \mathrm{mRNA}$ levels in patients with low-degree neurological deficit as opposed to those with severe deficiency. ${ }^{19}$ Studies on the secretion of IL4 and IL10 during both clinical periods report inconsistent results. We evaluate the tendency of increase in IL4 levels during remission compared with the relapse as an act of anti-inflammatory mediator activity, confirmed by experimental data: elevated levels of IL4 reduce the severity of EAE; antiIL $4 \mathrm{mAb}$ treatment significantly increased IFNgamma secreting cells. ${ }^{5,20}$ Similar data have been obtained by D. Franciotta et al. for statistically significant enhanced secretion of IL4 from PBMC during remission. ${ }^{21} \mathrm{~K}$. Hohnoki et al. report just the opposite - significantly higher concentrations of IL4 in relapse. ${ }^{13}$ The result for statistically significant lower levels of IL4 during exacerbation compared to controls is a manifestation of immune disbalance in patients. There were no significant differences in the dynamics of IL10 levels. V. Ozenci et al. prove the anti-inflammatory activity of IL10: suppressed expression of class II molecules on Human Leukocyte Antigens (HLA), of adhesion and costimulatory molecules on monocytes, macrophages and dendritic cells. K. Kahl et al. report significantly elevated levels of IL10mRNA in patients in relapse compared with healthy subjects. B. Cannella et al. record exacerbations of EAE after administration of IL10 in doses higher than the physiological doses. ${ }^{22-24}$ 
Similar to the results of this study are the data reported by C. Brandäo et al. ${ }^{3}$ No correlation was detected between changes in the deficit and serum concentrations of the cytokines during both clinical periods. We assume that the regulatory cytokine disbalance and EDSS scale reflect with different specificity the intensity of immune inflammation. The degree of neurological deficit is directly related to the loss of axons, but axonal damage have different mechanisms - immune-inflammatory, degenerative, ischemic. In the group under observation unlike other observations no significant differences were found in the dynamics of $25(\mathrm{OH}) \mathrm{D}$ levels in both periods and between patients and controls. ${ }^{8,9}$ The recorded significant negative correlation between changes in the deficit during the two phases and serum concentrations of $25(\mathrm{OH}) \mathrm{D}$ is established also by other authors. ${ }^{25}$ Complex analysis of detected tendencies and statistically significant relationships between changes in survey indicators are of interest. During exacerbation - a phase with aggravated neurological deficit, there is dominance of Th1, Th17-mediated secretion of IFN-gamma, IL17 cytokine, 25(OH)D levels border the threshold adopted for deficit $(\leq 25 \mathrm{nmol} / \mathrm{l})$. During remission, a phase with reduced degree of neurological deficit, there is dominance of $\mathrm{CD} 4+, \mathrm{CD} 25+$ Foxp3-mediated synthesis of TGF $\beta 1$ and Th2 mediated production of IL4, serum concentrations of 25(OH)D increase. Clinical observations provide evidence for the potential of vitamin D to induce an anti-inflammatory cytokine secretion of IL4, IL5, IL10. J. Smolders et al. detected a positive correlation between serum concentration of $25(\mathrm{OH}) \mathrm{D}$ and $\mathrm{T}$ regulatory function. Treatment in patients with RRMS, 1000 IU vitamin D, significantly increases TGF $\beta 1$ levels in serum compared to untreated..$^{19}$ At the current stage no detectable causal relationship is found between changes in cytokines and 25(OH)D levels.

\section{CONCLUSIONS}

Persistent cytokine disbalance in patients compared to controls is indicative of Th1-mediated CNS demyelination.

Anti-inflammatory cytokines, TGF $\beta 1$, IL4 are indicators of the immune response intensity.

Neurological deficit severity is not related to changes of the studied cytokines, but correlates negatively with changes in $25(\mathrm{OH}) \mathrm{D}$ serum levels during periods of relapse and remission.

\section{REFERENCES}

1. Wu GF, Alvarez E. The immunopathophysiology of multiple sclerosis. Neurol Clin 2011;29:257-78.

2. Hollifield RD, Harbige LS, Pham-Dinh D, et al. Evidence for cytokine dysregulation in multiple sclerosis: peripheral blood mononuclear cell production of pro-inflammatory and anti-inflammatory cytokines during relapse and remission. Autoimmunity 2003;36(3):133-41.

3. Brandão CO, Ruocco HH, Farias AS, et al. Cytokines and intrathecal $\operatorname{IgG}$ synthesis in multiple sclerosis patients during clinical remission. Arq Neuropsiquiatr 2005;63(4):914-19.

4. Hellings N, Gelin G, Medaer R, et al. Longitudinal study of antimyelin T-cell reactivity in relapsingremitting multiple sclerosis: association with clinical and MRI activity. J Neuroimmunol 2002;126(12):143-60.

5. Kallaur AP, Oliveira SR, Colado Simão AN, et al. Cytokine profile in relapsing-remitting multiple sclerosis patients and the association between progression and activity of the disease. Mol Med Rep 2013;7(3):1010-20.

6. Smolders J, Damoiseaux J, Menheere P, et al. Vitamin $\mathrm{D}$ as an immune modulator in multiple sclerosis, a review. J Neuroimmunol 2008;194(1-2):7-17.

7. Szodoray P, Nakken B, Gaal J, et al. The complex role of vitamin $D$ in autoimmune diseases. Scandinavian J Immunol 2008;68:261-9.

8. Smolders J, Menheere P, Kessels A, et al. Association of vitamin D metabolite levels with relapse rate and disability in multiple sclerosis. Mult Scler 2008;14:1220-4.

9. Kampman MT, Steffensen LH, et al. Effect of vitamin $\mathrm{D}_{3}$ supplementation on relapses, disease progression, and measures of function in persons with multiple sclerosis: exploratory outcomes from a double-blind randomized controlled trial. Mult Scler 2012;18(8):1144-51.

10.Peelen E, Knippenberg S, Muris A-H, et al. Effects of vitamin $D$ on the peripheral adaptive immune system: A review. Autoimmunity Rev 2011;10(12):733-43.

11. Pozuelo-Moyano B, Benito-León J. Vitamin D and multiple sclerosis. Rev Neurol 2013;56(4):243-251.

12. Lysandropoulos AP, Jaquiery E, Jilek S, et al. Vitamin $\mathrm{D}$ has a direct immunomodulatory effect on CD8+ T cells of patients with early multiple sclerosis and healthy control subjects. J Neuroimmunol 2011;233(1-2):240-4.

13. Hohnoki K, Inoue A, Koh CS. Elevated serum levels of IFN-gamma, IL-4 and TNF-alfa / unelevated serum levels of IL-10 in patients with demyelinating disease during acute stage. J Immunol 1998;87:27-32. 
14.Pouly S, Becher B, Blain M, et al. Interferon-gamma modulates human oligodendrocyte susceptibility to Fas-mediated apoptosis. J Neuropathol Exp Neurol 2000;59:280-6.

15. Stewart N, Taylor B, Ponsonby AL, et al. The effect of season on cytokine expression in multiple sclerosis and healthy subjects. J Neuroimmunol 2007; 188:181-6.

16. Brucklacher-Waldert V, Stuerner K, Kolster M, et al. Phenotypical and functional characterization of $\mathrm{T}$ helper 17 cells in multiple sclerosis. Brain 2009;132:3329-41.

17.Zhou L, Chong MW, Littman DR. Plasticity of CD4+ T Cell lineage differentiation. Immunity 2009;30:646-55.

18. Hofstetter HH, Gold R, Hartung H-P. Th17 cells in MS and experimental autoimmune encephalomyelitis. Int MSJ 2009;16(1):12-18.

19. Mahon BD, Gordon SA, Cruz J, et al. Cytokine profile in patients with multiple sclerosis following vitamin D supplementation. J Neuroimmunol 2003;143:128-32.

20.Boonstra A, Barrat FJ, Crain C, et al. $1 \alpha, 25$ dihydroxyvitamin D3 has a direct effect on native
CD4+ T cells to enhance the development of Th2 cells. J Immunol 2001;167:4974-80.

21. Franciotta D, Zardini E, Bergamaschi R, et al. Interferon-gamma and interleukin-4 producing T-cells in multiple sclerosis peripheral blood. Eur Cytokine Netw 2000;11(4):677-81.

22. Ozenci V, Kouwenhoven M, Huang YM, et al. Multiple sclerosis is associated with an imbalance between tumour necrosis factor-alpha (TNF-alpha)and IL-10-secreting blood cells that is corrected by interferon-beta (IFN-beta) treatment. Clin Exp Immunol 2000;120(1):147-53.

23. Kahl KG, Kruse N, Faller H, et al. Expression of tumor necrosis factor-alpha and interferon-gamma mRNA in blood cells correlates with depression scores during an acute attack in patients with multiple sclerosis. Psychoneuroendocrinology 2002;27(6):671-81.

24. Cannela B, Gao YL, Brosnan C, et al. IL-10 fails to abrogate experimental autoimmune encephalomyelitis. J Neurosci Res 1996;45:735-46.

25. Neau JP, Artaud-Uriot MS, Lhomme V, et al. Vitamin D and multiple sclerosis. A prospective survey of patients of Poitou-Charentes area. Rev Neurol 2011;167:317-23. 